\title{
Social Responsibility and Consensus Orientation in Public Governance: a Content Analysis
}

\author{
Nina Tomaževič \\ University of Ljubljana, Faculty of Public Administration, Slovenia \\ nina.tomazevic@fu.uni-lj.si \\ https://orcid.org/0000-0001-8126-1971
}

Received: 30. 7.2019

Accepted: 28. 10. 2019

\section{ABSTRACT}

Over the past two decades, social responsibility (SR) has become a key principle of many private sector entities that aim for business excellence. Similarly, in the public sector, the latest public governance models (PGMs) are based on the selected public governance principles (e.g. consensus orientation, participation, equity and inclusiveness) directed at connecting and including all types of stakeholders in decision-making and carrying out the activities of public sector organisations. Yet, there is insufficient reliable empirical evidence with respect to the relationship between social responsibility and the underlying principles of PGMs. The principal goal of the article is thus to identify the relationship between the concept of social responsibility and consensus orientation, which is one of the main theoretically and practically grounded principles of PGMs. This goal is addressed by applying the QDA Miner software package and analysing the contents of the 100 most relevant scientific papers from the Web of Science database. Specifically, the relationship between occurrence of the 'consensus orientation' principle and SR is identified and quantified, revealing the importance of the latter. Moreover, different PGMs are analysed in terms of consensus orientation and SR enforcement, providing tangible guidelines to help advance theory and practice in the domain of public governance.

Keywords: consensus orientation, content analysis, literature review, governance models, public sector, social responsibility

JEL: H83, M14

\section{Introduction}

Social responsibility (SR) is addressed in numerous theoretical works (Baumgartner, 2014; Cantele and Zardini, 2019; Dahlsrud, 2008; Del Mar Alonso-Almeida and Llach, 2018; Tiba, van Rijnsoever and Hekkert, 2018) and 
many organizations are attempting to put it into practice. It is used (sometimes even abused, e.g. in marketing purposes (Kvasić, Cerović and Olgić Draženović, 2017)) in several ways in theory and practice, with a vastly different scope and very dissimilar consequences. In general, social responsibility may be defined as a way of systemic thinking, managing and acting in order to achieve the mission and the strategic and tactical goals of the organization where all activities are directed to coordinating and satisfying the needs and expectations of all of the organization's stakeholders. This approach is wider than philanthropic activities alone and care for the environment on one hand, and includes society as a whole (as an abstract notion) on the other. A systematic and holistic approach to considering and satisfying all stakeholders' interests may prove vital for an organization's financial and nonfinancial performance as well as its long-term development (Mulej, Ženko and Žakelj, 2017; Šarotar Žižek and Mulej, 2013; Tomaževič, 2014).

The above broad definition implies that social responsibility can (must?) also be applied in the public sector, not only the private one (Aristovnik and Jaklič, 2013). Social responsibility concept can be applied to public organizations since they are, like private entities, made up of human beings. The concepts of ethics and social responsibility should apply to both sectors, especially when one notes the public sector in some countries accounts for up to $50 \%$ of GDP (Di Bitetto, Chymis and D'Anselmi, 2015). More importantly, public sector organizations around the world are responsible for physical and social infrastructure as well as the legal environment in which businesses operate (Chymis, D'Anselmi, and Triantopoulos, 2017). Several authors have already studied the social responsibility concept in the public sector (Formánková, Hrdličková and Grabec, 2017; Sangle, 2010; Steurer, Martinuzzi, and Margula, 2012). Chymis, D'Anselmi and Triantopoulos (2016) claim that no business (for-and non-profit) operates in a vacuum, but does so within the institutional environment whose creation is a primary responsibility of the public sector.

Many international organizations seek to increase public sector efficiency and effectiveness although rarely is the term 'responsibility' used in the process, despite being implicit in the literature on economics. When the International Monetary Fund (IMF), Organization for Economic Cooperation and Development (OECD), United Nations (UN), World Economic Forum (WEF) or the World Bank (WB) publish reports guiding public administrations worldwide how to raise their levels of transparency, accountability and integrity, the similarities with the social responsibility jargon are obvious (Chymis, D'Anselmi and Triantopoulos, 2016). In 2005, the OECD published a report on Modernizing Government that highlighted the need to make the public sector more effective and efficient with respect to spending constituents' resources, where one may argue that long-run efficiency and effectiveness come close to the concept of social responsibility (Chymis et al., 2017). While it is beyond doubt that public management must implement the basic social responsibility concepts of accountability and transparency, in practice this refers to the millions of people who are employed in public sector (Chymis et al., 2016). 
'Mainstream (Corporate) Social Responsibility ((C)SR)' is a notion confined to for-profit organizations (corporations/enterprises) (Di Bitetto, Chymis and D'Anselmi, 2015). The European Commission says (C)SR is the responsibility of enterprises for their impact on society and it should, therefore, be company-led. Companies can become socially responsible by (1) integrating social, environmental, ethical, consumer, and human rights concerns into their business strategy and operations, and (2) following the law. Public authorities should play a supporting role via voluntary policy measures and, where necessary, complementary regulation (EC, 2019). This definition relates to the concerns of social responsibility only to the challenges facing corporations/ enterprises. The other organizations that make up the economy and the social fabric are not mentioned. Is it therefore reasonable to assume that other organizations, e.g. public sector organizations and civil society organizations, are socially responsible per se and hence we do not need socially responsible management and governance in the public sector? The assumption the government is accountable per se is based mostly on the Weberian view, which assumes that organizations work as perfect and rational automata, behaving exactly as they should on paper. In Max Weber's view, the normative and the positive approach are the same, there is no difference between the conditional and the indicative tenses of reality. This is very much what is embodied in administrative law and in any law that specifies what the government should do (Di Bitetto et al., 2015).

Although Weber perceives stability as the chief objective of public organizations, Downs (1967) tends to conceive the high degree of stability in public bureaucracies as a perennial problem because it prevents the public sector from dynamically adapting to changes in society and new conditions for public governance. The Weberian view of the benevolent bureaucrat is unable to explain the irresponsible actions observed within public sector governance and management (Di Bitetto et al., 2015). The advocates of New Public Management (NPM) (Lane, 2000; Osborne and Gaebler, 1993) stressed the need for improved competitive conditions in case of a public-goods provider, i.e. public organizations had to adopt more entrepreneurial mind-sets and tools so as to operate in a more competitive way, to be driven by their mission (offering high-quality services to citizens), to be no longer being driven by bureaucracy, to become results-oriented and customer-driven, thereby empowering citizens/customers, local communities, industry associations, suppliers, media, non-governmental organizations (NGOs) and other stakeholders to become active in policy-setting and implementation. Principal-agent theory (specific for the New Public Management era) explains how public sector managers and employees encounter dilemmas similar to those faced by enterprises' managers and employees. Moreover, the public sector is largely unaffected by the elections that take place, on average, every four years. According to Sørensen and Torfing (2011), NPM has two limitations when seen from a public innovation perspective: (1) it builds a dogmatic assertion that the main source of efficiency-enhancing innovation arises from imitating the competitive logic in the private sector; and (2) it places the responsibility for public sector innovation solely on the shoulders of public managers. These 
are some of the reasons explaining why the public sector needs to increase its accountability, transparency and integrity, and become more socially responsible (Chymis et al., 2016).

In recent decades, a new stream of thought has gained ground, composed of hybrid models and revisiting approaches to classical administrative patterns, also suggesting that the dividing line between public and private sectors be reconsidered (Lampropoulou and Oikonomou, 2016). Modern public governance recognizes the need for inclusive and holistic approaches rather than mainly operating in isolation from the environment and the many stakeholders involved in the activities of public sector organizations. Along these lines, alternative governance models started appearing in the 1980s with the aim of enabling a better response to the challenges brought by modern society (Bach and Bordogna, 2011; Fraczkiewicz-Wronka and Wronka-Pospiech, 2018; Ropret, Aristovnik and Kovač, 2018).

As described above, despite public sector organizations having a different primary goal than private sector organizations, in the last few decades the governance models have been becoming ever more similar when the systematic involvement of all stakeholders of an institution is in question (Chymis, D'Anselmi and Triantopoulos, 2016; Author, 2014). Contemporary public governance models are based on different principles. Some principles are connected with social responsibility as defined above. These are, for example: (1) consensus orientation, (2) participation, and (3) equity and inclusiveness. For the purposes of this paper, consensus orientation was selected as the principle most fundamentally connected with the above definition of social responsibility.

Consensus orientation is the governance principle that emerged in public governance models when they became holistic and integrative - the main and most common PGMs including consensus orientation are New Weberian State, Good Governance, Network Governance models, Collaborative Governance models, etc. Pollitt and Bouckaert (2011, p. 19) describe the New Weberian State (NWS) as 'an attempt to modernize traditional bureaucracy by making it more professional, efficient, and citizen-friendly', reflecting 'a more optimistic and trusting attitude towards the state apparatus than the NPM'. NWS builds on the ideas of Max Weber and his rational bureaucracy. According to Bringselius and Thomasson (2017), the central paradigms in the NWS are transparency, performance measurement and stability. The primary aim of NPM reforms is to increase efficiency and flexibility. With the NWS, there is a stronger focus on quality issues, particularly issues relating to legality and equal treatment. This is also why the NWS focuses more on the input and process aspects of organization, whereas NPM concentrates on the output aspects. Good governance has eight major characteristics. It is participatory, consensus-oriented, accountable, transparent, responsive, effective and efficient, equitable and inclusive and follows the rule of law. It implies a high level of partnership and consensual decision-making among the various stakeholders. This allows 
all relevant stakeholders to become involved, thereby enabling society to be more inclusive and collaborative (UN, 2009; Vigoda, 2002).

Sørensen and Torfing (2005) believe a governance network is a relatively stable horizontal articulation of interdependent, yet operationally autonomous actors who interact via negotiations that involve bargaining, deliberation and intense power struggles which occur within a relatively institutionalized framework of contingently articulated rules, norms, knowledge and social imaginaries. It is self-regulating within the limits set by external agencies and which contribute to the production of public purpose in the broad sense of visions, ideas, plans and regulations. The core reasons for the emergence of governance networks are: (1) resource dependencies and the need for more integrated services (Klijn, 2008; Koppenjan and Klijn, 2004); and (2) to achieve more efficient and appropriate solutions by combining the resources and knowledge of many different actors and stakeholders (Frederickson, 2005). Governance networks involve a large number of interdependent actors who interact in order to serve the public purpose (Sørensen and Torfing, 2005). Collaborative public governance models are network-based models with an emphasis on the relations with stakeholders understood as citizens, non-governmental organizations, or entrepreneurs. The main rules governing the exercise of authority are participation and consultation, openness, responsiveness, transparency, accountability, and sustainable development. From the management point of view, the manager must take actions that will ensure the stakeholders' support (Bryson, 2007; Fraczkiewicz-Wronka and Wronka-Pospiech, 2018; McGuire, 2006; Vigoda, 2002). The other contemporary governance models related to Network Theory, which presumes a plurality of co-dependent stakeholders who contribute to the formation of quality public services, are New Public Governance (NPG), Digital Era Governance, etc. (Ropret, et al., 2018).

The foremost goal of the study was to identify and analyse the relationship between the concept of social responsibility and the public governance principle of 'consensus orientation'. Related with the latter, the fields of social responsibility and consensus orientation were also studied in the context of their development and enforcement within public governance models by applying methods of scientific analysis. Thus, the research goal was operationalized based on three research questions:

- RQ1: What are the dynamics regarding the publication frequency over the period of time?

- RQ2: What is the relationship between the occurrence of a consensus orientation and enforcement of social responsibility?

- RQ3: Which PGMs are mainly related to the enforcement of both a consensus orientation and social responsibility?

To address the above research questions, a content analysis (CA) was chosen as the central method for the analysis. This method provides a theory and set of techniques for extracting information from textual data regardless of the discipline. Unlike text analysis (TA), CA aims to quantify and categorize the 
content or meaning of certain textual configurations (words, word combinations, sentences etc.). Combining qualitative and quantitative content analysis techniques in this way brings many benefits. For example, quantitative content analysis may be useful as an tool or exploration prior to qualitative coding by allowing one to identify subtle differences in word usage between subgroups of individuals, or to quickly find the most common topics of phrases (Ropret and Aristovnik, 2018). Restricting the analysis to segments associated with specific codes may also be useful for identifying potential words or phrases associated with those codes. One may then use the QDA Miner text retrieval tool to identify other segments to which this code may be assigned. Quantitative content analysis might also prove useful after qualitative coding has been performed (Suerdem, 2014). Following the introduction, the paper consists of a more detailed description of the methods used in the study, a results section, a discussion and a conclusion.

\section{Methodology}

The primary goal of the research was achieved by following an original methodology that had three consecutive research phases. The first phase consisted of identifying all relevant publications (papers, books/book chapters) in the Web of Science (WoS) database, one of the most respected sources of research literature in the world. Based on 30 keywords, all possibly relevant scientific papers related to public governance models in the fields of public administration, political science and law were downloaded from the WoS database. This led to over 11,000 publications within the timespan 1992 to 2016 being identified. Thus, it was taken into account that papers need at least two to three years after publication to accumulate enough citations for bibliometric analysis to be reliable (Abramo, Cicero \& D'Angelo, 2011; Belter, 2015; Wang, 2013). In the second phase, these papers were thoroughly evaluated with a view to narrowing the broad set of papers down to the 100 most relevant ones. This step was facilitated by two complementary indicators based on the total citation count (global citation score - GCS) and citations per year (GCS/year) - the 100 highest overall ranking WoS papers with a focus on public governance models were identified, downloaded and separated from less relevant ones. This phase provided the input for the third research phase. The latter entailed applying the content analysis method (Ropret and Aristovnik, 2018).

In the next step, a content analysis was performed to address the goal of the paper. The QDA Miner 5.0.11 software package was used as the main tool for the content analysis. QDA Miner is a qualitative data and text analysis (TA) software package for coding textual data and annotating, retrieving and reviewing coded data and documents. Besides its text analysis features, QDA Miner provides a wide range of exploratory tools to determine patterns in coding and relationships between assigned codes and other numerical or categorical variables (Suerdem, 2014). Its seamless integration with WordStat, a quantitative content analysis and text-mining module, gave us the flexibility needed for analysing the text and relating its content to structured information, includ- 
ing numerical and categorical data (Ropret and Aristovnik, 2018). As a basis for the analysis, the QDA miner dictionary presented in Table 1 was designed, comprising categories (capital letters) and category keywords (italic letters).

The research goal was operationalized, based on the already presented research questions RQ1 to RQ3. As far as RQ1 is concerned, descriptive statistics were derived from the WoS database and QDA miner, whereas addressing $\mathrm{RQ} 2$ and RQ3 required a co-occurrence analysis based on QDA miner proximity plots. The proximity plot was the most accurate way of graphically representing the distance between objects by displaying the measured distance from a selected code to all other codes on a single axis. Therefore, it proved particularly valuable in extracting information on the governance principle and PGM relationship from the huge amount of publications contained in our database.

Table 1: The QDA miner dictionary

\begin{tabular}{lll}
$\begin{array}{c}\text { PUBLIC GOVERNANCE } \\
\text { (SUB)MODELS }\end{array}$ & \multicolumn{1}{c}{$\begin{array}{c}\text { SOCIAL } \\
\text { RESPONSIBILITY }\end{array}$} & \multicolumn{1}{c}{$\begin{array}{c}\text { CONSENSUS } \\
\text { ORIENTATION }\end{array}$} \\
- Weberian (bureaucracy) & - (Corporate) social & - Consensus (oriented) \\
- Old Public Administration & responsibility & - Consensus (orientation) \\
- NPM (New Public & - Socially respons* & - Consensus-oriented \\
Management) & - Societal responsibility & - Consensus-orientation \\
- POST-NPM & - Societal* respons* & - Consensual \\
- NWS (New Weberian State) & - CSR & \\
- Good Governance & & \\
- Digital-Era & & \\
- Collaborative Governance & & \\
- Network Governance & & \\
- Interactive Governance & & \\
- Public Service Model & & \\
- Public Value Model & & \\
- New Public Service & & \\
- Holistic Governance & \\
- Intelligent Governance & \\
- Hybrid Governance & \\
- Co-Production &
\end{tabular}

Source: own.

\section{Results}

The research results are presented in the following order: (1) the dynamics regarding publication frequency over the period of time (subsection 3.1), (2) the relationship between consensus orientation and social responsibility (subsection 3.2), and (3) the role of PGMs in enforcing both a consensus orientation and social responsibility (subsection 3.3). 


\subsection{Publication frequency}

The research results show growing research interest in the topic of public governance models (PGM) (Figure 1). In 1992, less than 100 publications a year were relevant, with the number rising to 259 units in 2000 and even further in 2008 (619) and later on. Among these PGM publications, those where social responsibility (SR) or consensus orientation were identified as elements (in abstract, title, keyword) were growing; namely, up until 1998 three or less publications per year were identified, the number rose to 18 in 2008 and even to 45 in 2016. Yet, in 2016 both SR and consensus-related publications together represent just $2.5 \%$ of cases, indicating the quite marginal attention then being paid by researchers. The most covered sources in terms of publication frequency included highly respected journals in the public administration field, underlining the relevance and quality of our methodological approach: International Review of Administrative Sciences, International Journal of Public Sector Management, Public Administration, Public Management Review, International Journal of Public Administration, and Public Administration Review. This reveals the growing attention during the quest to find socially responsible public governance models following the global social and financial crisis in 2008 and the subsequent challenges related to societal (e.g. demographic issues, migration issues, the rise of extremist right-wing parties, populism) and environmental (e.g. pollution, exploitation of natural resources, harming animal and human health) issues, and several others calling for an efficient and effective response by public sector institutions.

Figure 1: Web of Science (WoS) publications on public governance models (1992-2016): number of papers per year

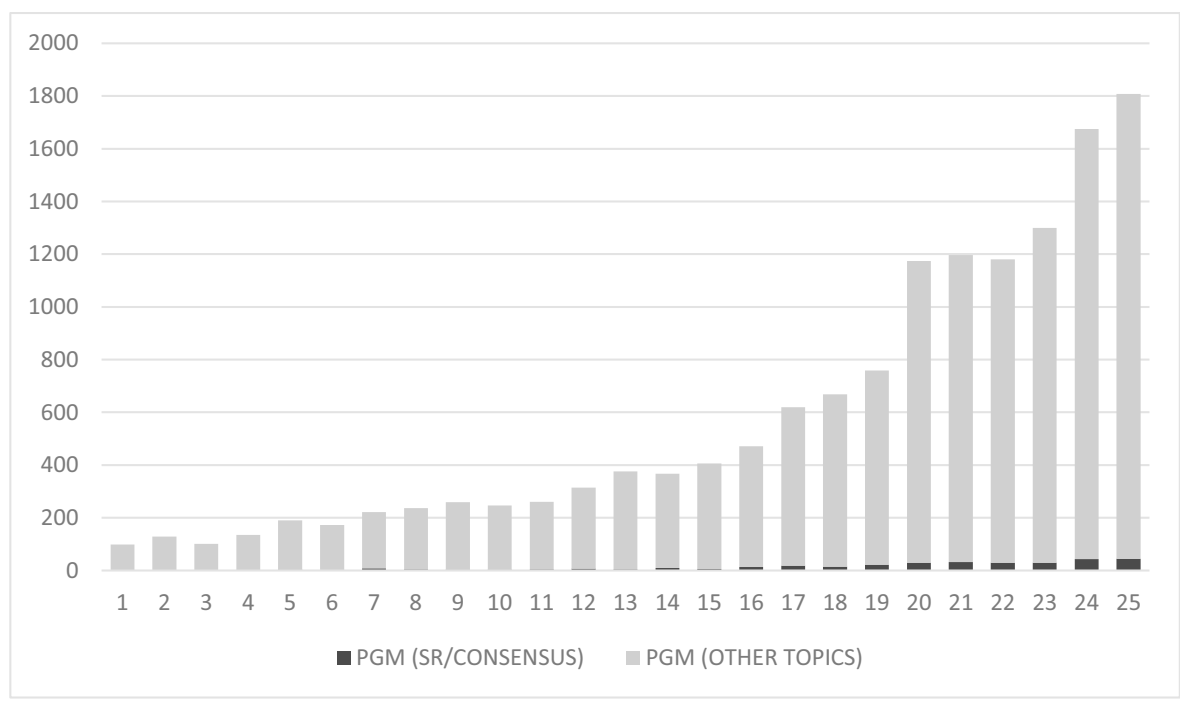

*abscise axis: $1=1992,17=2008$ and $25=2016$

Source: Authors' own calculation based on the database created $(N=14,366)$ 


\subsection{Relationship between a consensus orientation and enforcement of social responsibility}

The co-occurrence analysis (Table 2 ) indicates the relationship between SR and a consensus orientation based on the occurrence of both terms as defined by the QDA miner dictionary (Table 1). Table 2 shows the calculated values for Jaccard's similarity index $(\mathrm{J})$, which considers the similarity between two operational taxonomic units as the number of attributes shared, divided by the total number of attributes present in either of them (Real, 1998). Based on Jaccard's index values, we immediately notice both SR and consensus orientation demonstrate significant co-occurrence. The result $(\mathrm{J}=0.017)$ indicates that both elements may be properly fostered only when taking their interrelated nature and (possible) synergies derived from the latter into account.

Table 2: The relationship between consensus orientation and social responsibility enforcement in the literature: Jaccard's index (statistically significant results shown $(P \leq 0.05)$ )

$\begin{array}{cccccc}\text { Target } & \text { Keyword } & \text { Co-occurs } & \text { Do not } & \text { Absent } & \text { Jaccard } \\ \begin{array}{c}\text { SOCIAL } \\ \text { RESPONSIBILITY }\end{array} & \text { CONSENSUS } & 11 & 192 & 449 & 0.017\end{array}$

Source: Authors' calculations, based on applied database of most relevant publications $(\mathrm{N}=100)$.

\subsection{Role of public governance models in enforcing a consensus orientation and social responsibility}

Building on the interrelated nature of both a consensus orientation and social responsibility, as previously indicated, the next step was aimed at identifying the PGMs, which may represent the main drivers, that enforce both of these governance elements (Table 3). The values of Jaccard's similarity index (J) show it is particularly the post-New Public Management governance models that are significantly enforcing a consensus orientation and social responsibility:

- Alternative governance models $(J=0.016)$,

- Network governance model $(J=0.013)$,

- New Weberian State (NWS) $(J=0.011)$. 
Table 3: The relationships between PGMs, social responsibility and consensus orientation enforcement in the literature: Jaccard's index (statistically significant results shown $(P \leq 0.05)$ )

$\begin{array}{cccccc}\text { Target } & \text { Keyword } & \text { Co-occurs } & \text { Do not } & \text { Absent } & \text { Jaccard } \\ \text { SOC. RESP. \& CONS. } & \text { Alternative models } & 12 & 270 & 448 & 0.016 \\ \text { SOC. RESP. \& CONS. } & \text { Network Governance } & 8 & 135 & 452 & 0.013 \\ \text { SOC. RESP. \& CONS. } & \text { New Weberian State } & 6 & 107 & 454 & 0.011\end{array}$

Source: Authors' calculations, based on the created database of most relevant publications $(\mathrm{N}=100)$.

The results reveal that pluralistic or Western (post-NPM) governance paradigms may be well suited for enforcing both the social responsibility and consensus-orientation elements, while at the same time the quest for alternative governance paradigms may prove to be particularly rewarding.

\section{Discussion}

The changing trends seen in the economy, society and the environment over the last decades call for fresh approaches to the ways individuals, businesses, NGOs and public sector organizations function. The focus on research has been on the latter, specifically on public governance models studied by many researchers in the last 25 years. First, the research has shown growing research interest in the topic of public governance models, as indicated in (RQ1). At the same time, the important PGM elements of social responsibility and consensus orientation were revealed to be interrelated, therefore requiring an integrated approach to most successfully fostering both (RQ2). However, the social responsibility and consensus orientation paradigms may relatively be well suited for subjective, pluralistic, or Western (post-New Public Management (post-NPM)) governance paradigms (RQ3). Still, it remains questionable whether such pluralistic models can help effectively tackle administrative challenges in less developed and developing states. In Central and Eastern Europe, for example, there are regional and historical specifics in governance developments such as over-detailed regulation which hinders the resolution of complex administrative issues (like migrations, digitalization, demographic, and environmental changes, etc.). Moreover, it can be observed that most post-NPM authors belong to the Anglo-American-Australasian group of countries, followed by Continental European and Nordic countries (Ropret and Aristovnik, 2018). We must therefore recognize the indication that the shortfall in research concerning other regions may itself limit the reliability of scientific guidelines about implementation. The need for further PGM research within these underrepresented regions is highlighted by the fact that, compared to the good foreign practices of reforming public administration and developing new governance models, comprehensive interdisciplinary approaches are often missing in these countries In addition, the lack of infrastructure, skilled 
and ethical professionals and insufficient funding clearly pose further obstacles to effectively tackling social responsibility and consensus orientation in the least developed administrative contexts. Further, good-governance and the related post-NPM governance model research, built on the principle of a plurality of co-dependent stakeholders and sustainable development, still lack reliable evidence on the successful implementation of social responsibility and consensus orientation. This underlines the importance of further PGM research in establishing a basis for public governance characterized by systematically directed interactions between stakeholders as well as preventing and solving conflicts with a view to shared long-term prosperity.

\section{Conclusion}

All developed countries wish to achieve the effective and efficient socially responsible governance and management of their institutions and projects, yet these issues become even more sensitive when talking about developing countries. Namely, public sector organizations influence many dimensions of citizens' lives, they employ large numbers of people, spend taxpayers' money, cooperate with institutions from other countries and invest in different areas of the economy, society and the environment; that are the key pillars of sustainable development. They should therefore be held accountable for the long-term welfare of a country, and their socially responsible decisions and activities should tend to achieve the consensus of all relevant stakeholders when short- and long-term decisions are being made. This is even more important during periods of crisis like that we faced after 2007/2008. The problems which emerged over the last decades and are accumulating on an exponential scale are so big they can only be decelerated or solved by quick and engaged actions of numerous stakeholders working in close cooperation while being socially responsible and trying to reach consensus while making decisions on future development. The research results presented in the paper reveal that, on average, after 2009 the number of papers discussing social responsibility and consensus orientation in the context of public governance models started to grow, reaching more than twice that level by 2016. Moreover, our analysis clearly underlines the interrelated nature of both a consensus orientation and social responsibility. In this regard, pluralistic (postNPM) governance paradigms, such as Network Governance and New Weberian State have been indicated to be relatively well suited for enforcing both social responsibility and consensus orientation. The results also reveal that the quest for establishing alternative governance paradigms may prove even more rewarding as regards an integrated approach towards social responsibility and consensus orientation. Such public governance alternatives shall put more focus on hybrid approaches, focused on a strong mutual capacity-building element across the full range of activities, all participating stakeholders being aware of one another's core interests and a culture of joint learning and crosscutting capacity-building (Donner, Theocharidis, \& Johansson, 2018). Normally, it is not be possible to effectively address such multidimensional challenges of governance in the short term (Bigg and Wood, 2004). Yet, the 
studied papers already provide some qualitative and quantitative evidence, including case studies, meaning there is a growing interest in these topics in both theory and practice. This can fill us with optimism that there is a desire on the national and international levels to make the public sector an important driver of a better future for all of us and future generations as well.

\section{Acknowledgements}

The author gratefully acknowledges that the project The Development of a Holistic Governance Model for an Efficient and Effective Slovenian Public Administration (J5-8238) was financially supported by the Slovenian Research Agency. 


\section{References}

Abramo G., Cicero T. and D'Angelo C.A. (2011). Assessing the Varying Level of Impact Measurement Accuracy as a Function of the Citation Window Length. Journal of Informetrics, 5(4), pp. 659-667.

Aristovnik, A. and Jaklič, K. (2013). Job Satisfaction of Older Workers as a Factor of Promoting Labour Market Participation in the EU: The Case of Slovenia. Revija za socijalnu politiku, 20(2), pp. 123-148.

Bach, S. and Bordogna, L. (2011). Varieties of New Public Management or Alternative Models? The Reform of Public Service Employment Relations in Industrialized Democracies. The International Journal of Human Resource Management, 22(11), pp. 2281-2294.

Belter, C. W. (2015). Bibliometric Indicators: Opportunities and Limits. Journal of the Medical Library Association, 103(4), pp. 219-221.

Baumgartner, R. J. (2014). Managing Corporate Sustainability and CSR: A Conceptual Framework Combining Values, Strategies, and Instruments Contributing to Sustainable Development. Corporate Social Responsibility and Environmental Management, 21, pp. 258-271.

Bigg, T. and Ward, H. (2004). Linking Corporate Social Responsibility, Good Governance and Corporate Accountability through Dialogue. A Discussion Paper, International Institute for Environment and Development, London (24 December).

Bringselius, L. and Thomasson, A. (2017). Balancing Stability and Change in the New Weberian State. Statsvetenskaplig tidskrift, At <https://www. researchgate.net/profile/Louise_Bringselius/publication/313445084_ Balancing_stability_and_change_in_the_new_Weberian_state/ links/58f5e3e7aca27289̄c21da48̄9/Balancing-stability-and-change-in-thenew-Weberian-state.pdf>, accessed 23 July 2019.

Bryson, J. M. (2004). What to do when Stakeholders matter: Stakeholder Identification and Analysis Techniques. Public Management Review, 6(1), pp. 21-53.

Campbell, J. L. (2007). Why would corporations behave in socially responsible ways? An institutional theory of corporate social responsibility. Academy of management, 32(3), pp. 946-967.

Cantele, S. and Zardini, A. (2019). What drives small and medium enterprises towards sustainability? Role of interactions between pressures, barriers and benefits. Corporate Social Responsibility and Environmental Management. At <https://onlinelibrary.wiley.com/doi/abs/10.1002/csr.1778?af=R\&utm_ source=feedburner\&utm_medium=feed\&utm_campaign=Feed\%3A+Corpo rateSocialResponsibilityAndEnvironmentalMañagement+\%28Corporate+S ocial+Responsibility+and+Environmental+Management\%29>, accessed 24 October 2019.

Chymis, A., D'Anselmi, P. and Triantopoulos, C. (2016). The Need for a Responsible Public Administration. In A. Theofilou, ed., G. Grigore, ed., and A. Stancu, ed., Corporate Social Responsibility in the Post-Financial Crisis Era. London: Springer Nature, pp. 155-173.

Chymis, A., D'Anselmi, P. and Triantopoulos, C. (2017). Integrating Social Responsibility into Public Institutions, Organizations, and Administration. In P. M. Flynn, ed., M. Gudic, ed., and T. K. Tan, ed., Beyond the Bottom Line: Integrating Sustainability into Business and Management Practice. Austin: Greenleaf Publishing, pp. 162-174. 
Dahlsrud, A. (2008). How Corporate Social Responsibility is Defined: An Analysis of 37 Definitions. Corporate Social Responsibility and Environmental Management, 15, pp. 1-13.

Del Mar Alonso-Almeida, M. and Llach, J. (2018). Socially responsible companies: Are they the best workplace for millennials? A cross-national analysis. Corporate Social Responsibility and Environmental Management, pp. 1-10.

Di Bitetto, M., Chymis, A. and D'Anselmi, P. (2015). Public Management as Corporate Social Responsibility. In M. Di Bitetto, A. Chymis, and P. D'Anselmi, eds., Public Management as Corporate Social Responsibility. At <https:// www.springer.com/gp/book/9783319070360>, accessed 15 July 2019.

Donner, P., Theocharidis, G. and Johansson, T. (2018). Methods to Promote Improved Governance in Maritime Administrations of Developing Nations. Corporate Social Responsibility in the Maritime Industry, pp. 63-89. Springer, Cham.

EC - European Commission (2019). Corporate Social Responsibility \& Responsible Business Conduct. At < https://ec.europa.eu/growth/industry/corporatesocial-responsibility_nn>, accessed 15 July 2019

Formánková, S., Hrdličková, A. and Grabec, T. (2017). Corporate Social Responsibility of Public Administration through Eyes of Enterprises. Acta Universitatis Agriculturae et Silviculturae Mendelianae Brunensis, 65(6), pp. 1901-1909.

Fraczkiewicz-Wronka, A. and Wronka-Pospiech, M. (2018). How Practices of Managing Partnerships Contributes to the Value Creation-Public-Social Partnership Perspective. Sustainability, 10, pp. 1-25.

Frederickson, H. G. (2005). What Happened to Public Administration? Governance, Governance Everywhere. In E. Ferlie, L. Lynn, and C. Pollitt, eds., The Oxford Handbook of Public Management. Oxford: Oxford University Press.

Klijn, E.-H., 2008. Governance and Governance Networks in Europe. Public Management Review, 10(4), pp. 505-525.

Koppenjan, J. F. M. and Klijn, E. H. (2004). Managing Uncertainties in Networks: A Network Approach to Problem Solving and Decision Making, London: Routledge.

Kvasić, S., Cerović L. and Olgić Draženović, B. (2016). Online Corporate Social Responsibility Reporting in the Croatian Banking Sector. International Public Administration Review, 14(4), pp. 9-26.

Lane, J. E. (2000). New Public Management. New York: Routledge.

Lampropoulou, M. and Oikonomou, G. (2016). Theoretical models of public administration and patterns of state reform in Greece. International Review of Administrative Sciences, 0(0), pp. 1-21.

McGuire, M. (2006). Collaborative Public Management: Assessing What We Know and How We Know It. Public Administration Review, Special issue, pp. 33-43.

Mulej, M., Ženko, Z. and Žakelj, V. (2017). Social Responsibility as a Next Step in Development of Systemic Behavior Toward Systems Solutions of Systemic Problems of Today. Journal of Systems Science and Systems Engineering, 26(3), pp. 287-302.

Osborne, D. and Gaebler, T. (1993). Reinventing government: How the entrepreneurial spirit is transforming government. New York: Plume. 
Pollitt, C. and Bouckaert, G. (2011). Public management reform: A comparative analysis - new public management, governance, and the neo-weberian state. Oxford: Oxford University Press.

Real, R. (1999). Tables of significant values of Jaccard's index of similarity. Miscellania Zoologica, 22(1), pp. 29-40.

Ropret, M. and Aristovnik, A. (2018). Public governance models: a systematic review of 30 years' research. In: Public administration for well-being and growth. Iaşi: NISPAcee, 2018. At <http://www.nispa.org/conf_paper_ details2018.php?cid=26\&p=4165\&pid=8308>, accessed 22 July $201 \overline{9}$.

Ropret, M., Aristovnik, A. and Kovač, P. (2018). A content analysis of the rule of law within public governance models: old vs. new EU member states. The NISPAcee journal of public administration and policy, 11(2), pp. 129-152. At <https://content.sciendo.com/view/journals/nispa/11/2/article-p129.xml>, accessed 22 July 2019.

Sangle, S. (2010). Critical Success Factors for Corporate Social Responsibility: A Public Sector Perspective. Corporate Social Responsibility and Environmental Management, 17, pp. 205-214.

Sørensen, E. and Torfing, J. (2015). The Democratic Anchorage of Governance Networks. Scandinavian Political Studies, 28(3), pp. 196-218.

Sørensen, E. and Torfing, J. (2011). Enhancing Collaborative Innovation in the Public Sector. Administration and Society, 43(8), pp. 842-868.

Srivastava, V. and Srivastava, L. R. (2018). A Review of Public and Private Sector Corporate Social Responsibility (CSR) Practices in India and Present State of Affairs. International Journal for Research in Engineering Application and Management, 4(8), pp. 1-6.

Steurer, R., Martinuzzi, A. and Margula, S. (2012). Public Policies on CSR in Europe: Themes, Instruments, and Regional Differences. Corporate Social Responsibility and Environmental Management, 19, pp. 206-227.

Suerdem, A. K. (2014). Workshop in Applied Analysis Software. At <http://abicqu. webfactional.com/test/wp-content/uploads/2014/02/4.-UCINET-Workshop. $p d f>$, accessed 26 June 2019.

Šarotar Žižek, S. and Mulej, M. (2013). Social Responsibility: A Way of Requisite Holism of Humans and Their Well-Being. Kybernetes: The International Journal of Systems and Cybernetics, 42(2), pp. 318-335.

Tiba, S., van Rijnsoever, F. J.and Hekkert, M. P. (2018). Firms with benefits: A systematic review of responsible entrepreneurship and corporate social responsibility literature. Corporate Social Responsibility and Environmental Management, pp. 1-20.

Tomaževič, N. (2014). Socially responsible management in public administration. In: M. Mulej and R. G. Dyck, eds., Social responsibility - sustainability, education and management, (Social responsibility beyond neoliberalism and charity). Bentham eBooks, pp. 200-228. At <http://www.eurekaselect. com/123211/chapter/socially-responsible-management-in-publicadministration>, accessed 15 July 2019.

(UN) United Nations. (2009). What is Good Governance? At <https://www. unescap.org/resources/what-good-governance>, accessed 27 July 2019.

Vigoda, E. (2002). From Responsiveness to Collaboration: Governance, Citizens, and the Next Generation of Public Administration. Public Administration Review, 62(5), pp. 527-540. 


\section{Nina Tomaževič}

Wang, J. (2013). Citation Time Window Choice for Research Impact Evaluation. Scientometrics, 94(3), pp. 851-872.

Ward, H. (2004). Public Sector Roles in Strengthening Corporate Social Responsibility: Taking Stock. Report of The World Bank Group's Investment Climate Department. At <https://pubs.iied.org/pdfs/16014lIED.pdf>, accessed 24 July 2019. 